\title{
MENINGKATKAN PARTISIPASI MASYARAKAT MELALUI PEMBANGUNAN INFRASTRUKTUR DI DESA SUKATANI KECAMATAN NGAMPRAH KABUPATEN BANDUNG BARAT
}

\section{Desi Arisanti Gustiyani}

Institut Keguruan Dan Ilmu Pendidikan Siliwangi

deasyarisanti07@gmail.com

\begin{abstract}
ABSTRAK
Partisipasi masyarakat dalam kebijakan pembangunan di negara-negara yang menerapkan demokrasi termasuk di Indonesia bukanlah hal yang baru. Partisipasi masyarakat merupakan suatu proses teknis untuk memberikan kesempatan dan kewenangan yang lebih luas kepada masyarakat secara bersama-sama untuk memecahkan berbagai persoalan. Sebagai suatu konsep dan praktek pembangunan, konsep partisipasi baru dibicarakan pada tahun 60-an ketika berbadai lembaga internasional mempromosikan partisipasi dalam praktek perencanaan, pelaksanaan, dan evaluasi pembangunan. Adapun tujuan dari penelitian ini: Untuk mengetahui gambaran kondisi masyarakat desa sukatani, untuk mengetahui partisipasi masyarakat dalam pembangunan infarstruktur, untuk mengetahui upaya-upaya peningkatan partisipasi masyarakat, dan untuk mengetahui faktor-faktor pendukung serta penghambat dalam upaya meningkatkan partisipasi. Metode penelitian yang digunakan dalam penelitian ini adalah disesuaikan dengan tujuan peneliti, maka metode penelitian ini menggunakan metode deskriptif kualitatif. Hasil penelitian melalui pra survei peneliti melihat secara langsung dikarnakan beredarnya isu bahwa partisipasi masyarakat dalam proses pembangunan belum sesuai yang diharapkan dan masih ada permasalahan terhadap parisipasi masyarakat dalam pembangunan di Desa Sukatani. Kesimpulan dari pemaparan diatas bahwasannya partisipasi masyarakat di Desa Sukatani masih tergolong rendah perlu adanya peningkatan dalam hal kesadaran dan kepedulian diri dari masyarsakat setempat bahwasannya penting berpartisipasi dalam menjaga, merawat, dan memelihara setiap hasil dari pembangunan desa yang sudah dilaksanakan .
\end{abstract}

Kata kunci : partisipasi masyarakat, pembangunan infrastruktur

\section{PENDAHULUAN}

Dalam pembangunan nasional secara pengelolaannya pasti melibatkan segenap aparat pemerintahan, baik ditingkat pusat maupun daerah bahkan sampai ditingkat desa. Komponen atau aparat dimaksud hendaknya memiliki kemampuan yang optimal dalam pelaksanaan tugasnya. Sangatlah tepat jika wilayah desa menjadi sasaran penyelenggaraan suatu program pembangunan, pemerintahan desa merupakan pemerintahan terendah dalam struktur pemerintahan indonesia yang sangat menentukan bagi berhasilnya usaha dalam pembangunan nasional yang menyeluruh. Partisipasi merupakan keikutsertaan seseorang di dalam kelompok sosial untuk mengambil bagian dari kegiatan masyarakatnya, di luar pekerjaan atau profesinya sendiri theodorson dalam (Andriani, $\mathrm{N}$. 
M. A., Rares, J. J., \& Tampi, G. B. 2017). Dalam proses pembangunan sesuai dengan UndangUndang Desa No.6 Tahun 2014 mengacu pada dua pola pendekatan yaitu Desa Membangun dan Membangun Desa yang mana bertujuan untuk meningkatkan kesejahteraan masyarakat desa dan kualitas hidup manusia serta penanggulangan kemiskinan melalui penyediaan pemenuhan kebutuhan dasar, pembangunan sarana prasarana, pembangunan potensi ekonomi lokal, serta pemanfaatan sumber daya alam dan lingkungan secara berkelanjutan.

Menurut Hoofsteede dalam Abdul Latif (2014:97) mengatakan bahwa partisipasi berarti ambil bagian dalam 1 tahap atau lebih dari suatu proses pembangunan. Dalam pengertian ini paling tidak dapat dijumpai adanya tiga hal pokok yaitu partisipasi merupakan keterlibatan mental emosional; partisipasi menghendaki adanya kontribusi terhapan kepentingan atau tujuan kelompok; da partisipasi merupakan tanggung jawab terhadap kelompok. Dari pendapat di atas dapat disimpulkan bahwa yang dimaksud partisipasi adalah merupakan peran serta warga desa baik dalam merencanakan, melaksanakan, mempertanggung jawabkan maupun dalam menerima hasil-hasil pembangunan. Partisipasi masyarakat dapat diartikan juga dengan keikutsertaan masyarakat secara langsung maupun tidak langsung seperti sumbangan dana, tenaga, pikiran, maupun pendapat. Bahkan partisipasi masyarakat tidak hanya diperlukan pada saat pelaksanaan saja akan tetapi mulai dari tahap perencanaan pengambilan keputusan.

Dalam partisipasi masyarakat di Desa Sukatani Kecamatan Ngamprah Kabupaten Bandung Barat melihat bahwa partisipasi masyarakat dalam proses pembangunan belum sesuai yang diharapkan dan masih ada permasalahan terhadap parisipasi masyarakat dalam pembangunan di Desa Sukatani. Dalam hal ini disarankan kepada pihak pemerintah agar lebih meningkatkan kesadaran dan kepedulian masyarakat Desa Sukatani dalam setiap program pembangunan yang akan dilakukan, misalnya memberikan sosialisasi dan bimbingan bagi masyarakat Desa mengenai pentingnya pembangunan, serta diharapkan kepada pemerintah desa dan masyarakat agar dapat menjalin hubungan kerjasama dalam mengawasi setiap jalannya kegiatan pembangunan Desa juga saling memberikan dukungan satu sama lain dalam setiap kegiatan pembangunan Desa. Besar harapan dengan adanya pembangunan infrastruktur di Desa Sukatani dapat meningkatkan partisipasi masyarakat dalam menjaga, merawat, dan memanfaatkannya dengan baik.

\section{LANDASAN TEORI}

Pengertian secara umum partisipasi adalah, keikutsertaan seseorang atau sekelompok anggota masyarakat dalam suatu kegiatan. Menurut Isbandi dalam (Andriani, N. M. A., Rares, J. J., \& Tampi, G. B. 2017) partisipasi masyarakat adalah keikutsertaan masyarakat dalam proses pengidentifikasian masalah dan potensi yang ada di masyarakat, pemilihan dan pengambilan keputusan tentang alternative solusi untuk menangani masalah, pelaksanaan upaya mengatasi masalah, dan keterlibatan masyarakat dalam proses mengevaluasi perubahan yang terjadi.

Hakekat pembangunan adalah transformasi atau perubahan dari suatu kondisi tertentu menuju suatu kondisi yang lebih baik. Dalam konteks kesejahteraan sosial pembangunan berarti upaya untuk memperbaiki/meningkatkan kesejahteraan masyarakat. (Chabib Soleh 2014:1) 
Pembangunan infrastruktur adalah suatu rangkaian yang terdiri atas beberapa bangunan fisik yang masing-masing saling mengkait dan saling ketergantungan satu sama lainnya. Menurut Grigg dalam (fifie rorong,jj rares, 2017: 6) infrastruktur merujuk pada sistem fisik yang menyediakan transportasi, pengairan, drainase, bangunan-bangunan gedung, dan fasilitas publik yang lain yang di butuhkan untuk memenuhi kebutuhan dasar manusia dalam lingkup sosial dan ekonomi.

\section{METODE PELAKSANAAN}

Metode penelitian yang digunakan dalam penelitian ini adalah atas dasar dari sejumlah masalah yang tertuang diidentifikasi masalah serta disesuaikan dengan tujuan peneliti, maka metode penelitian ini menggunakan metode deskriptif kualitatif.

Metode deskriptif dapat diartikan sebagai prosedur pemecahan masalah yang diselidiki dengan menggambarkan/melukiskan keadaan subyek/obyek penelitian: Seseorang, lembaga, masyarakat dan lain-lain pada saat sekarang berdasarkan fakta-fakta yang tampak, atau sebagaimana adanya Nawawi dalam (Hamid Dramadi, 2014)

Adapun Teknik pengumpulan data dalam penelitian ini pertama, Menggunakan Teknik wawancara kepada responden. Dalam melakukan wawancara ini dapat menggunakan pedoman atau secara bebas melakukan wawancara dengan responden. Kedua, memanfaatkan dokumentasi yang ada sebagai sumber informasi atau catatan pribadi yang relevan untuk memperoleh data yang diinginkan ke tiga, observasi kepada responden yang diteliti, dengan menggunakan alat bantu seperti, fhoto atau mencatat langsung. (Hamid Darmadi, 2014:272)

Dalam teknik analisi data kualitatif yaitu dengan reduksi data, penyajian data, dan kesimpulan atau verifikasi. Menurut (Sugiyono, 2013:248) mengemukakan bahwa aktivitas dalam analisis data kualitatif dilakukan secara interaktif dan berlangsung secara terus menerus sampai tuntas sehingga datanya sudah lengkap/sesuai. Peneliti dalam menganalisa data malakukan langkah-langkah pokok sebagai berikut : kegiatan proses analisa data dimulai dengan menelaah seluruh data dari berbagai sumber dan hasil seluruh teknik pengumpulan data, kemudian diadakan penyusunan data dilakukan selama pengumpulan sampai proses pengumpulan data selesai.

\section{HASIL DAN PEMBAHASAN}

\section{Hasil}

Badan Pusat Statistik Kabupaten Bandung Barat (2016) luas wilayah kecamatan Ngamprah 36,01 km², pada tahun 2015 banyaknya 11 Desa, 160 RW, 745 RT, dan 44.908 jumlah KK, yang mana banyaknya penduduk kecamatan ngamprah berjenis kelamin laki-laki sebanyak 84.474 dan perempuan 82.560 jumlah total 167.034. (Badan Pusat Statistik, 2016: 18-29) dengan ini kondisi atau keadaan masyarakat desa sukatani saat ini dalam berpartisipasi masih sangat tergolong rendah akan tetapi melalui pembangunan infrastruktur salah satunya pembangunan kios-kios masyarakat semakin meningkat tingkat kesadaran pentingnya berpartisipasi. Adapun upaya-upaya dalam peningkatan partisipasi masyarakat pemerintah desa sukatani mengundang masyarakat untuk bermusyawarah dalam mengambil keputusan, selanjutnya pemerintah desa melibatkan masyarakat untuk ikut 
serta dalam melaksanakan pembangunan infrastruktur tersebut serta menghimbau dan berharap dengan adanya beberapa pembangunan infrastruktur masyarakat akan semakin meningkat partisipasinya dalam hal apapun demi kemajuan bersama.Upaya dalam peningkatan partisipasi masyarakat tidak selalu berjalan mulus akan tetapi adanya faktor penghambat dan faktor pendudukung. Faktor penghambat dalam meningkatkan partisipasi masyarakat yang pertama kesibukan masyarakat dalam beraktivitas sehari-hari sehingga tidak dapat ikutserta disetiap program pembangunan, baik itu ikut serta dalam musyawarah ataupun pada saat pelaksanaan pembangunan. Kedua ketidak tahuan masyarakat dikarenakan kurangnya informasi tidak adanya yang mensosialisasikannya. Dan yang ketiga sebagian masyarakat kurang sadar dan tidak ingin ikut serta berpartisipasi dalam memajukan program yang akan dilaksanakan.Adapun faktor pendukung yaitu dengan adanya dana yang memadai dalam program pembangunan infrastruktur, adanya minat yang cukup tinggi disebagian masyarakat untuk ikut serta berpartisipasi dalam melaksanakannya program pembangunan infrastruktur agar meningkatkatkan dan memajukan masyarakat desa sukatani.

\section{Pembahasan}

Dari hasil survei diatas peneliti yang mana saat itu diberikan kesempatan dan izinnya untuk mewawancari secara langsung bapak kepala Desa Sukatani yang bernama Dede Supriadi, yang mana beliau mengatakan " Pemerintah di desa sukatani tahun 2017 mendapat bantuan dana dari pemerintah pusat dan dialokasikan untuk pembangunan sarana dan prasarana masyarakat sesuai dengan rencana anggaran belanja desa yaitu ada 10 kios yang dibangun pemerintah desa dan sekarang diserahkan kepada Badan Usaha milik desa (Bumdes) yang diketuai oleh Bapak Tia Setia, anggaran tersebut sejumlah kurang lebih Rp 400.000.000 yang dipergunakan untuk pengerukan tanah yang tadinya lapang sukatani, sewa beku dan lain-lainnya kemudian sisanya untuk pembangunan kioskios tersebut. Dengan harapan mudah-mudahan dengan adanya kios tersebut khususnya masyarakat sukatani bisa menikmati, meningkatkan perekonomian dan bisa berkembang sesuai dengan harapan masyarakat sehingga masyarakat sukatani bisa semakin maju dan mandiri. Selain pembangunan bumdes juga ada pembangunan penghotmikkan jalan sepanjang 1050 meter dengan lebar 2,5 meter dari dua anggaran yaitu anggaran dana desa dari Rw 02 sampai Rw 03100 juta dan dari bantuan keuangan menghabiskan dana 100 juta yaitu dari Rw 03 sampai Rw 08, selain itu juga untuk kirmir/tembok penahan tanah dilokasi Rt 03 Rw 08 sebesar 42 juta dari dana desa.

Dalam kegiatan pembangunan infrastruktur Desa Sukatani Kecamatan Ngamprah Kabupaten Bandung Barat mengadakan program pembangunan desa yang dianggarankan baik itu dari Pemerintah Pusat maupun dari Kabupaten, semuanya telah dilaksanakan untuk anggaran di tahun 2017. Dalam hal ini disarankan kepada pihak pemerintah agar lebih meningkatkan kesadaran dan kepedulian masyarakat Desa Sukatani dalam setiap program pembangunan yang akan dilakukan, misalnya memberikan sosialisasi dan bimbingan bagi masyarakat desa mengenai pentingnya pembangunan, serta diharapkan kepada pemerintah desa dan masyarakat agar dapat menjalin hubungan kerjasama dalam mengawasi setiap jalannya kegiatan pembangunanDesa juga saling memberikan dukungan satu sama lain dalam setiap kegiatan pembangunan Desa. Badan Pusat Statistik Kabupaten Bandung Barat (2016) luas wilayah kecamatan Ngamprah 36,01km², pada tahun 2015 
banyaknya 11 Desa, 160 RW, 745 RT, dan 44.908 jumlah KK, yang mana banyaknya penduduk kecamatan ngamprah berjenis kelamin laki-laki sebanyak 84.474 dan perempuan 82.560 jumlah total 167.034. (Badan Pusat Statistik, 2016: 18-29)

Dalam rangka mencapai tujuan pembangunan desa yang diharapkan, tentunya diperlukan keterlibatan seluruh masyarakat sebagai pelaku pembangunan. Keikutsertaan masyarakat dalam hal pembangunan infrastruktur yang akan dibangun di Desa Sukatani adalah kesadaran yang tidak dapat muncul dengan sendirinya, oleh karena itu agar kesadaran masyarakat dapat muncul perlu adanya bimbingan dan arahan dari pemerintah desa. Maka dengan adanya keterlibatan bimbingan dari pemerintah desa suatu pembangunan akan dirasakan secara merata dan partisipasi masyarakat dalam pembangunan infrastruktur desa sangat diharapkan agar dapat memberikan masukan kepada pemerintah desa apa yang sebenarnya mereka butuhkan. Partisipasi masyarakat yang muncul adalah suatu dukungan dari mereka yang merupakan dukungan bagi pemerintah desa untuk memenuhi kebutuhan dasar mereka. Oleh karna itu dengan tidak adanya partisipasi masyarakat dalam pembangunan infrastruktur ini dipastikan tidak akan bisa melaksanakan pembangunan desa dengan baik. Berikut ini adalah merupakan pembahasan yang didapat berdasarkan indikator-indikatoryaitu:pertama Partisipasi dalam pengambilan keputusan. Partisipasi ini bersifat sangat penting karna pengambilan keputusan merupakan suatu proses pemilihan alternatif berdasarkan pertimbangan yang menyeluruh dan bersama. Dibutuhkan kesepakatan dan suara mufakat karena bagaimanapun juga kegiatan terselenggara demi kepentingan bersama. Adapun wujud partisipasi masyarakat dalam pengambilan keputusan ini seperti: menghadiri rapat, diskusi, sumbangan pikiran, tanggapan atau penolakan terhadap program yang ditawarkan.keduaPatisipasi dalam pelaksanaan ini adalah jenis partisipasi yang menjadi salah satu unsur dalam penentu keberhasilan program itu sendiri. Ruang lingkup partisipasi dalam pelaksanaan meliputi menggerakan sumber daya dan dana, kegiatan administratif dan koordinasi serta penjabaran program. Ketiga Partisipasi dalam pengambilan manfaat adalah partisipasi yang terkait dengan kualitas dan kuantitas dari hasil pelaksanaan program pembangunan yang dicapai. Dan keempat Partisipasi dalam evaluasi bertujuan untuk mengetahui bagaimana pelaksanaan program berjalan, apakah sudah sesuai dengan tujuan yang ingin dicapai atau tidak. (Afifah Dwi Astuti, 2015:17)

Menurut sumaryadi dalam (Andriani, N. M. A., Rares, J. J., \& Tampi, G. B, 2017: 7) partisipasi berarti peran serta seseorang atau kelompok masyarakat dalam proses pembangunan baik bentuk pernyataan maupun dalam bentuk kegiatan dengan memberikan masukan pikiran, tenaga, waktu, keahlian, modal dan atau materi, serta ikut memanfaatkan dan menikmati hasil-hasil pembangunan. Dari pengerian di atas jelas bahwa partisipasi masyarakat merupakan faktor penting dalam pembangunan untuk tumbuh dan berkembangnya pembangunan desa. Upaya tumbuh dan dan berkembangnya partisipasi masyarakat dalam pembangunan infrastruktur dapat diupayakan melalui kegiatan pemberdayaan masyarakat dengan melalui kegiatan komunikasi pembangunan. Tujuan komunikasi pembangunan bukanlah sekedar untuk memasyarakatkan pembangunan dan penyampaian pesan-pesan pembangunan saja, akan tetapi yang lebih penting adalah menumbuhkan, menggerakan, dan memelihara partisipasi masyarakat dalam proses pembangunan. 


\section{KESIMPULAN}

Berdasarkan hasil pengamatan, observasi dan wawancara yang dilakukan, maka peneliti menyimpulkan bahwa terdapat perubahan dan peningkatan dalam hal partisipasi masyarakat di Desa Sukatani Kecamatan Ngamprah Kabupaten Bandung Barat, baik ikut serta dalam hal musyarawah, ataupun ikut serta dalam pelaksanaan pembangunan, merawat, menjaga, dan memanfaatkan dengan baik. Dalam hal ini tentunya masyarakat dan pemerintah desa saling bekerja sama dan mendukung satu sama lain. Tentunya dalam segi ekonomi pun bagi masyarakat yang asalnya tidak berpenghasilan jadi memiliki penghasilan dan bagi masyarakat yang terlalu jauh untuk berbelanja ke pasar dengan adanya kios-kios semakin terbantu berbelanja semakin lebih dekat. Walau pada saat itu Partisipasi masyarakat di Desa Sukatani Kecamatan Ngamprah masih tergolong rendah dikarnakan kesadaran dan kepedulian masyarakat dalam menghadiri rapat/musyawarah untuk membahas dan menghasilkan suatu program pembangunan infrastruktur desa hanya dihadiri oleh beberapa orang atau perwakilan masyarakat saja, namun dengan hasil yang sudah tebentuk beberapa bangunan infrastruktur yang ada, masyarakat sadar akan pentingnya menjaga, merawat, dan melestarikan juga menfaatkan pembangunanpembangunan yang ada, sehingga dengan adanya pembangunan infrastruktur di Desa Sukatani Kecamatan Ngamprah Kabupaten Bandung Barat masyarakat setempat semakin meningkat berpartisipasi dalam hal apapun. Salah satunya masyarakat dapat memanfaatkan menempati kios-kios yang sudah dibangun dengan mulai berjual-beli yang dikelola oleh Badan Usaha Milik Desa (BUMDES).

\section{DAFTAR PUSTAKA}

Andriani, N. M. A., Rares, J. J., \& Tampi, G. B. (2017). Partisipasi Masyarakat dalam Pembangunan di Desa Tumokang Baru Kecamatan Dumoga Utara Kabupaten Bolaang Mongondow. JURNAL ADMINISTRASI PUBLIK, 3(046).

Astuti, D. F. (2013). Partisipasi Masyarakat Dalam Pembangunan Masyarakat Desa Melalui Usaha Mikro Pengolahan Susu Kambing Etawa di Tlogoguwo, Kaligesing, Purworejo, Jawa Tengah. Dalam Skripsi (tidak diterbitkan)

Badan Pusat Statistik, (2016) Badan Pusat Statistik Kabupaten Bandung Barat Dalam Angka, Bandung, Cv Nuraha

Darmadi, H (2014). Metode Penelitian Pendidikan dan Sosial Teori Konsep Dasar dan Implementasi, Bandung, Alfabeta

Latif, A. (2014). Peran partisipasi masyarakat dalam peningkatan pembangunan desa di kecamatan posigadan. dalam Jurnal Madani, 4(1).

RORONG, F., \& Rares, J. J. (2017). Partisipasi Masyarakat dalam Pembangunan Infrastruktur di Desa Tolombukan Satu Kecamatan Pasan Kabupaten Minahasa Tenggara. JURNAL ADMINISTRASI PUBLIK, 3(046).

Soetomo (2012). Pembangunan Masyarakat Merangkai Sebuah Kerangka, Yogyakarta, PUSTAKA BELAJAR.

Soleh, C (2014). Dialektika Pembangunan Dengan Pemberdayaan, Bandung, FOKUSMEDIA. 
Sugiyono. (2012:15). Metode Penelitian Pendidikan:Pendekatan Kuantitatif,kualitatif, dan R\&D. Bandung: Alfabeta. 